\title{
Subarachnoid, Subdural and Interdural Spaces at the Clival Region: An Anatomical Study
}

\author{
Klival Bölgede Subaraknoid, Subdural ve Interdural Mesafeler: \\ Anatomik Çalışma
}

Giyas AYBERK ${ }^{1}$, Mehmet Faik OZVEREN², Sevil ASLAN ${ }^{1}$, Mesut Emre YAMAN ${ }^{1}$, Onur YAMAN ${ }^{3}$, Selim KAYACI ${ }^{4}$, Ibrahim TEKDEMIR ${ }^{5}$

${ }^{1}$ M.H. Ataturk Training and Research Hospital, 2nd Department of Neurosurgery, Ankara, Turkey

${ }^{2}$ Rize University, Faculty of Medicine, Department of Neurosurgery, Rize, Turkey

${ }^{3}$ M.H. Rize Training and Research Hospital, Department of Neurosurgery, Rize, Turkey

${ }^{4}$ Sar Hospital, Department of Neurosurgery, Rize, Turkey

${ }_{5}^{5}$ Ankara University, Faculty of Medicine, Department of Anatomy, Ankara, Turkey

Correspondence address: Giyas AYBERK / E-mail: giyas67@hotmail.com

\begin{abstract}
AIM: We aimed to show the significance of the anterior pontine membrane as a determining structure between the subdural and subarachnoid space in the clival region.

MATERIAL and METHODS: Five adult cadaver heads and five cerebral hemispheres were used. The skull vault and hemipheres were removed by sectioning through the pontomesencephalic junction. Five other heads hemispheres were removed but the arachnoid membrane was protected and the cerebral side of the clival dura mater was dissected. In another specimen, the dural porus of the abducens nerve was sectioned for histological evaluation. Three cases of hematoma at the clivus were presented to support our findings.

RESULTS: The anterior pontine membrane is the arachnoid membrane forming the anterior wall of the prepontine cistern with its lateral extension at the skull base. This membrane forms the subdural and subarachnoid spaces by forming a barrier between the clival dura mater and neurovascular structures of the brainstem. There were rigid fibrous trabeculations between both cerebral and periosteal dural layers forming the basilar plexus as the interdural space in the clivus.

CONCLUSION: The anterior pontine membrane separates the subdural and subarachnoid spaces at the clival region. The hematomas of the clival region require to be evaluated with consideration given to the existance of the subdural space.
\end{abstract}

KEYWORDS: Anterior pontine membrane, Arachnoid, Clivus, Interdural space

ÖZ

AMAÇ: Bu çalışmada, klival bölgedeki subdural ve subaraknoid mesafenin belirlenmesinde anterior pontin membranın önemini göstermek istedik.

YÖNTEM ve GEREÇ: Çalışmada beş yetişkin kadavranın kafatası ve beş serebral hemisfer kullanılımıştır. Kafatası ve hemisferler pontomezensefalik bileşke boyunca kesilerek çıkarılmıştır. Diğer beş hemisfer, araknoid membran korunarak çıkarılmış ve klival duramaterin serebral kısmı diseke edilmiştir. Bir başka spesmende, abdusens siniri dural porusu civarında histolojik kesit almak için kesilmiştir. Bulguları desteklemek için üç klival hematom vakası sunulmuştur.

BULGULAR: Anterior pontin membran, prepontin sisternin anterior duvarını oluşturur ve kafa kaidesinin lateraline doğru uzanır. Bu membran, beyin sapının nörovaskuler yapıları ve klival dura dura mater arasında bariyer oluşturarak, subdural ve subaraknoid mesafenin oluşmasını sağlar. Klivusta baziler pleksusu oluşturan serebral ve periostal dural tabakalar arasında rijit fibröz trabekülasyonlar vardı.

SONUÇ: Anterior pontin membran, klival bölgede subdural ve subaraknoid mesafeleri ayırır. Klival bölgedeki hematomların, subdural mesafenin varlığı göz önüne alınarak değerlendirilmesi gerekir.

ANAHTAR SÖZCÜKLER: Anterior pontin membran, Araknoid, Klivus, İnterdural mesafe 


\section{INTRODUCTION}

Although the subdural space (SDS) and subarachnoid space (SAS) terms are clearly defined as being in the calvarial region, there is little account concerning both of these anatomical spaces of the clival part of the brain (29). The inner layer of the dura mater and external layer of the arachnoid mater are adjacent to the calvarial region, and there is no space between them (11). However, the differences between these layers can be obtained radiologically, as a result of advances in magnetic resonance imaging (MRI) technology such as the availablity of 3 Tesla devices and much more sophisticated software. In this study, we aimed to show the inadequately explained structure of the meningeal layers in the clival region and to emphasize the significance of the anterior pontine membrane (APM) as a determining structure between the subdural and subarachnoid space, through the use of cadaveric examination. Additionaly, the radiological imaging showing epidural, subdural and subarachnoid hemorrhage obtained from some of our cases were included into the discussion to clarify both terms in clinical practice.

\section{MATERIAL and METHODS}

\section{Cadaveric study}

Five adult cadaver heads and 5 cerebral hemispheres obtained from the Department of Anatomy, School of Medicine, Ankara University were examined using $2.4 x$ to $12 x$ magnification. The skull vault and hemipheres were removed by sectioning through the pontomesencephalic junction in order to study the area between the pons and clivus in the five heads. These heads were embalmed in a $10 \%$ formalin solution. The cerebral side of the clival dura mater was dissected to observe internal membranous structure of the clivus dura mater. The hemispheres with cerebellum were removed from the cranium by protecting the arachnoid membrane coverage in the other 5 heads. In another specimen, the portion surrounding the dural entrance porus of the abducens nerve was sectioned and stained with hematoxylin and eosin to enable study under light microscopy, as in the examination of the arachnoid membrane in the dural porus.

\section{RESULTS}

\section{Cadaver}

It was detected that the arachnoid membrane thickened gradually and laterally towards both sides at the skull base in which the hemispheres were removed. This thickening is known as the APM, according to a previous report regarding this area (16) (Figure $1 \mathrm{~A}$ ). The space between the clivus and the APM is the SDS with the arachnoid membrane coming in to the porus around the sixth cranial nerve penetrating the dura mater of the skull base. The SDS extended into the porus of the sixth cranial nerve between the dura and arachnoid mater. The space between the pons and the APM is the SAS, containing the basilar artery and its perforating branches together with the pontine veins. The SAS continued into the cranial nerve porus between the sixth cranial nerve and the arachnoid. The basilar plexus was exposed when the meningeal side of clival dura mater was dissected and removed. There were very strong and firm fibrous trabeculations between both dural layers (Figure 1B), with the periostal dura mater securaly attached to the clival bone. It was not possible to detach the periosteal dura mater from the clival bone without rigorous dissection, with a scalpel, in some parts of the basilar plexus.

It was observed that the APM engulfed all related structures from the anterior side in the specimens, so the cerebral

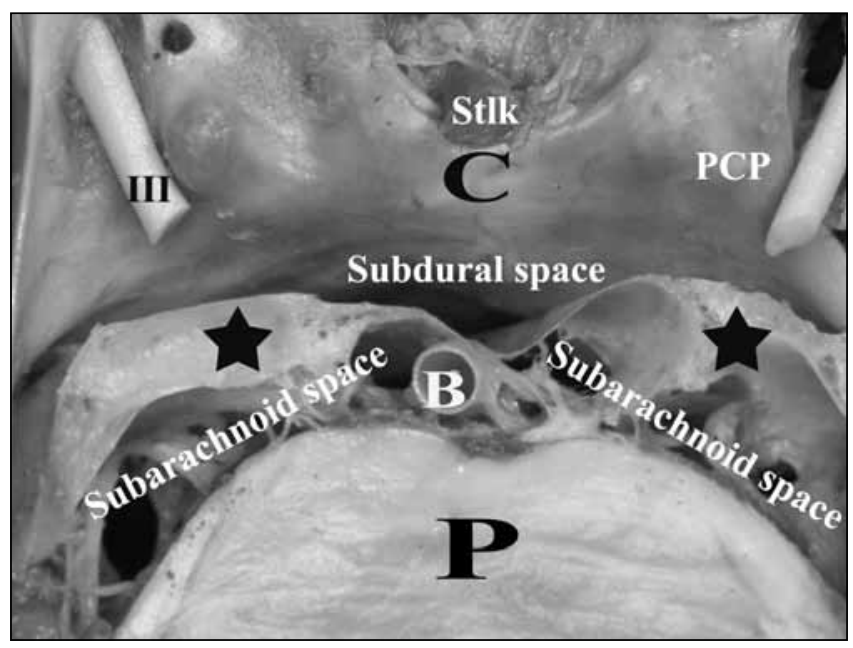

Figure 1A: Axial section at the pontomesencephalic region shows the relationship between the subarachnoidal and subdural space in the brainstem. The lateral extension of the anterior prepontine arachnoid membrane is known as the anterior pontine membrane (stars). Stlk: Pituitary stalk, C: Clivus, B: Basilar artery, P: Pons, PCP: Posterior clinoid proces.

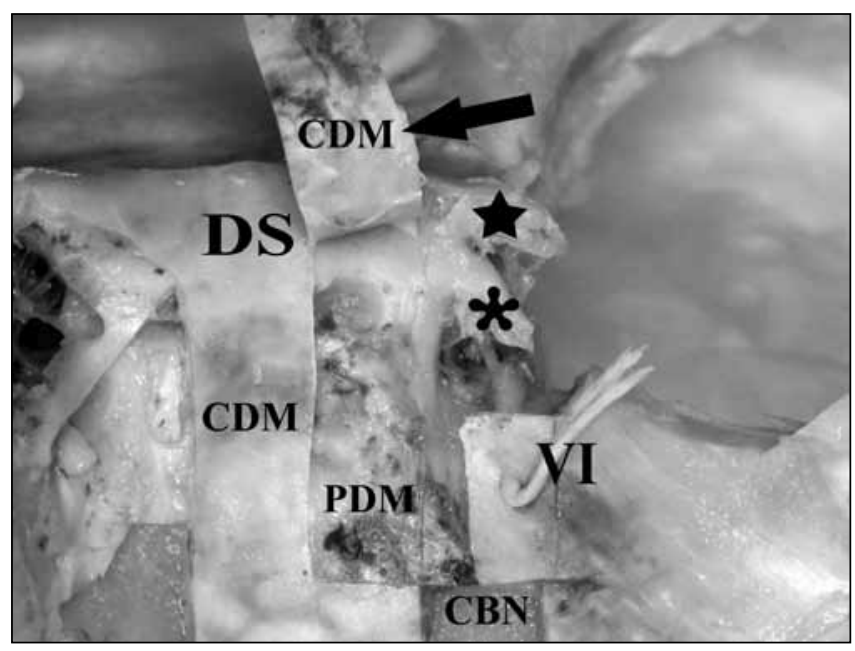

Figure 1B: Dissection of the cerebral dura mater in the petroclival region shows tight adhesion between the cerebral dura mater (CDM) and periosteal dura mater (PDM). The PDM is firmly attached to the clivus. The sixth nerve (VI) and arachnoid membrane are wrapped around the sleeve and enters into Dorello's channel under the petrosphenoidal ligament (asterix). DS: Dorsum sella, Star: Posterior clinoid process. 
hemispheres and the cerebellum were cautiously dissected and disconnected (Figure $1 \mathrm{C}$ ). Around the abducens nerve porus, the arachnoid membrane invaginated between the dural sleeve and the abducens nerve. The area between the dural sleeve and the arachnoid membrane corresponded to the SDS, with the area between the nerve and the arachnoid membrane corresponding to the SAS (Figure 1D, 2).

\section{Illustrative Cases}

Case 1: A 6-year-old female patient was admitted to the hospital following a fall. Her Glasgow coma scale (GCS) was 13 points. Computed tomography (CT) showed clival subdural hematoma (Figure 3). Hyperintensity denoting the blood has disappeared on the control CT posttraumatic 3rd day. The

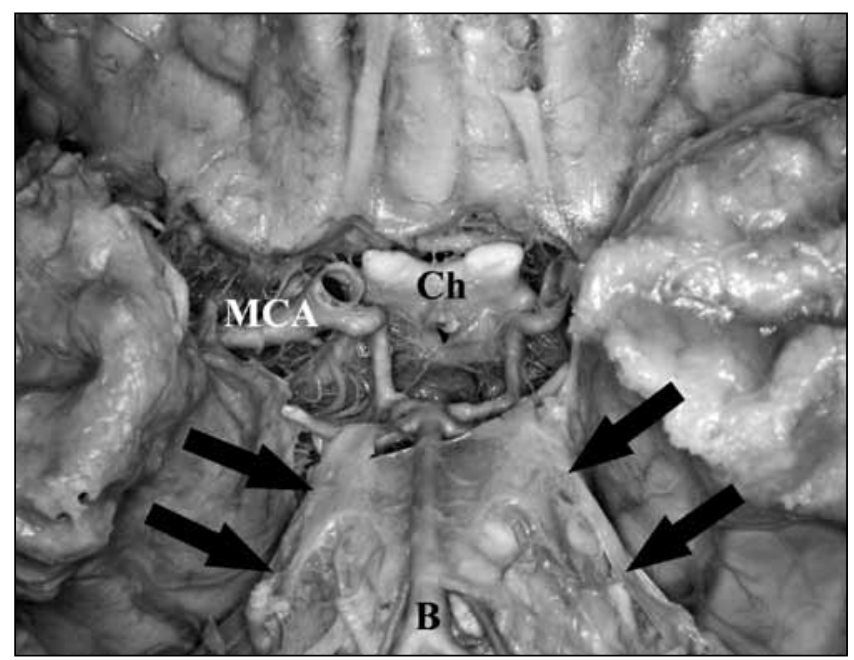

Figure 1C: The inferior view of the brain shows the relationship of the anterior pontine membrane with the brain stem and the basilar artery. Note how the membrane engulfs these structures (black double arrows). Ch: Optic chiasma, MCA: Middle cerebral artery, B: Basilar artery.

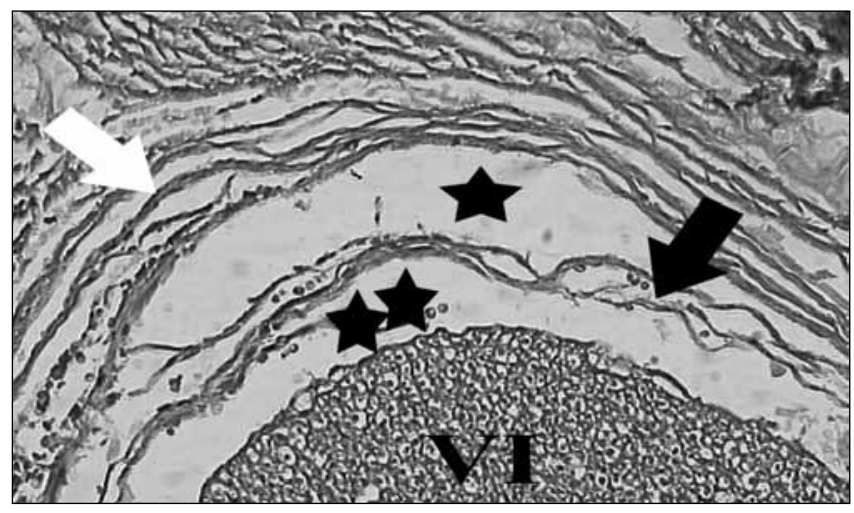

Figure 1D: A histological section taken from the abducens nerve entrance point shows engulfment of the sixth nerve (VI) by the dura (white arrow) and arachnoid mater (black arrow). The subdural space (star) and the subarachnoid space (double stars) were seen to be porus (HE 40x). patient was discharged on the fifteenth day of her admission with a GCS of 15 points.

Case 2: A 47-year-old female patient was admitted to the hospital after a fall of 3 meters. Her GCS was 13 points. There was otorrhea of the right ear. The CT showed right sided

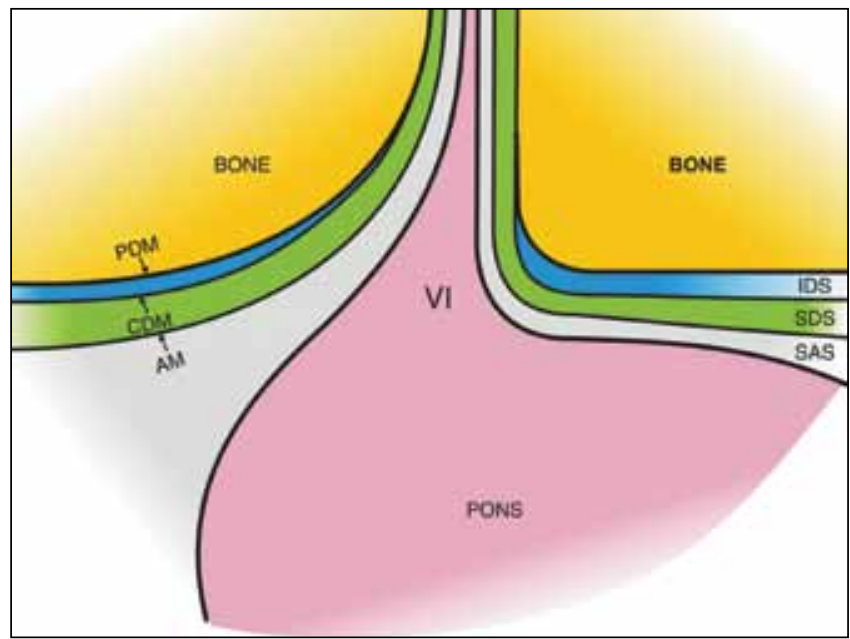

Figure 2: Schematic drawing of the dura and arachnoid mater around the abducens nerve (VI) entrance porus. Note the changing of the subdural space (SDS) and subrachnoid space (SAS) at clival, and the abducens nerve porus region. IDS: Interdural space, PDM: Periosteal dura mater, CDM: Cerebral dura mater, AM: Arachnoid membrane.

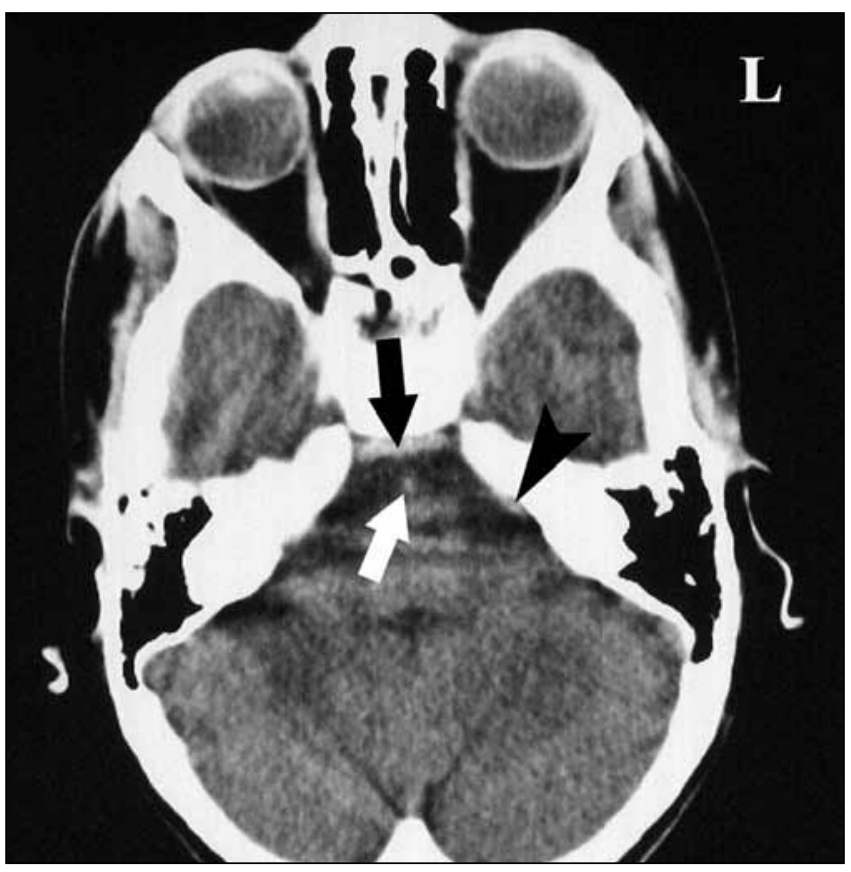

Figure 3:The computed tomography scan of case 1 shows subdural hemorrhage in the clival (black arrow) and the left petroclival region (black arrowhead). The subarachnoid space is free from blood. White arrow: basilar artery. 
fronto-parietal epidural hematoma, right-sided clival biconvex hematoma near the petrous apex, and subdural hematoma at the left clival region (Figure 4). There was hemorrhage in the sphenoid sinus due to a skull base fracture. The calvarial epidural hematoma was evacuated surgically because of a decrease in consciousness. The otorrhea disappeared postoperatively. The patient was discharged with a GCS of 15 on the postoperative 15th day.

Case 3: A 50-year-old male patient was admitted to the hospital with a subarachnoid hemorrhage. His GCS was 15 points and the neurological examination was normal, except for neck stiffness. A CT confirmed a subarachnoid hemorrhage in the prepontine cistern, with a hypodense image of cerebrospinal fluid filling in the clival region (Figure 5).

\section{DISCUSSION}

Enlarged areas of the SAS consisting of the intracranial cisterns, and cerebrospinal fluid (CSF) circulates throughout all portions of the SAS. There is no naturally occuring biological space at the dura-arachnoid juntion in the calvarial region (11). While the periosteal dura mater was attached tenaciously to the cranial base and includes more extracellular collagen, the meningeal dura mater has less extracellular collagen and the inner aspect, has a special cell layer known as the dural border cell (DBC) layer (8). The arachnoid membrane consists of two different cell layers; the arachnoid barrier cell $(A B C)$ layer, and the arachnoid trabeculea (11). The $A B C$ layer has tight junctions between the $A B C s$ which is peculiar to this layer (11). There is no possibility for space between the DBCs and the $A B C s$ (11). A pathology in this area, such as subdural hematoma, is the result of a separation of the DBCs (11). Therefore, the "subdural space" word, in clinical nomenclature, can be considered a debatable term in the calvarial region (11). However, our observation of the subdural space was found to be different at the skull base. A layer of arachnoid membrane extends from the dorsum sella posteriorly over the clivus (33). This layer can be distinguished at the anterior of the pons and with a gradual thickening increasing towards the lateral side. Thus, there is some confusion in the nomenculature, concerning the prepontine cistern arachnoid membrane. Matsuno et al. (16) have described lateral part (itself the arachnoid membrane) of the prepontine cistern arachnoid membrane as the APM. This paired membrane is between the prepontine and the cerebellopontine cisterns (16). It is preferable to include the arachnoid membrane, forming the anterior wall of the prepontine cistern, into the "anterior pontine membrane" terminology. As the APM clearly extends as a separate free layer without adhering to the clival dura mater, in our study (Figure 1A). It may be speculated that direct contact between the APM and dura mater was displaced during opening of the cranial vault. However, the waving of the APM in the CSF is a common observation when the Liliquest membrane is opened during the surgery. This type of observation can be also seen in MRI examinations of patients. In case 3, we observed that a subarachnoid hemorrhage collected in the prepontine cistern of the SAS

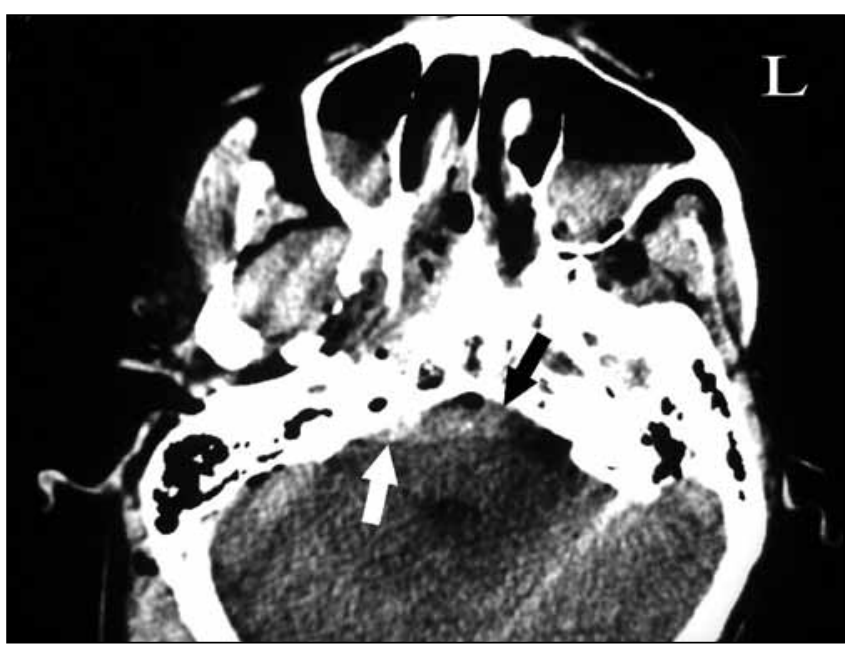

Figure 4: The computed tomography scan of the same patient shows a right-sided clival epidural hemorrhage (white arrow), and clival subdural hemorrhage (black arrow). Note the air bubble in the subdural space.

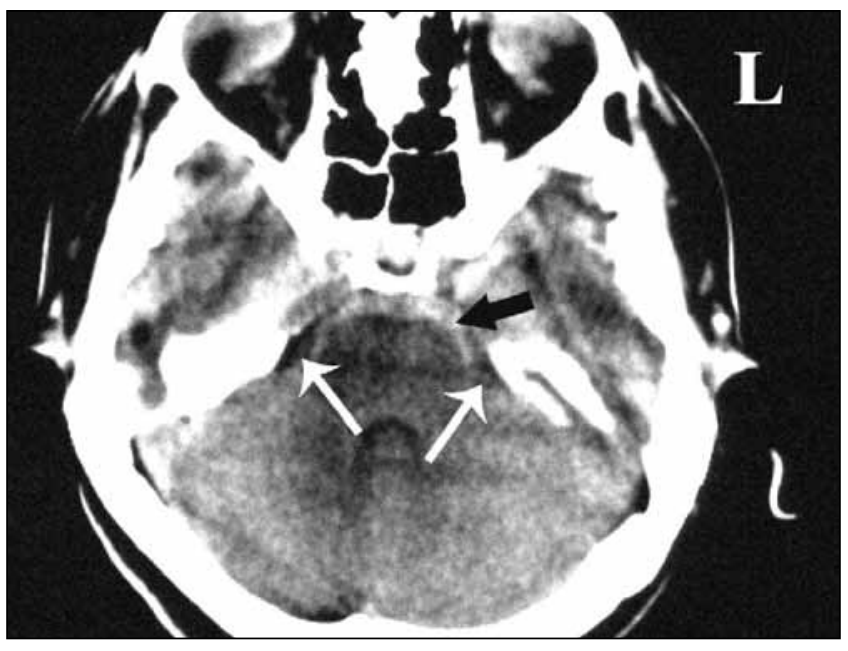

Figure 5: The computed tomography scan of case 3 shows the subarachnoid hemorrhage in the SAS (black arrow) and the SDS is protected from the blood (white arrow).

but the clival SDS did not show any hemorrhage (Figure 5). Our dissections verified the description of the DBC and the $A B C$ layer, without any potential space, may be specific to the calvarial region and not to the skull base region.

The APM, along with cranial nerves, invaginates through the dural pori of the cranial nerves, as was illustrated in the dural entrance porus of the abducens nerve, in this study (Figure 1D). This alignment emphasizes that the SAS, which is a continuation of the prepontine cistern at the clival region, lies between the abducens nerve and the arachnoid membrane within the nerve sleeve. Yaşargil (31) has commented that the cranial nerves, along with their arteries and veins, advance 
in the form of arachnoid packs in their own foramina. Direct contact of the CSF with cranial nerves extends inside their dural porus and sleeve presumably contributes to their nourishment $(7,21)$. A space between the clivus dura mater and arachnoid membrane is located inside the dural sleeve, as was confirmed by our dissections, and histological section. Arachnoid coverage of the cranial nerves inside their dural sleeve explains the avoidance of permanent injury after removal of tumors invading the cavernous sinus (12). Importance of the APM increased in as a result of using neuroendoscopic procedures recent years. Yaşargil (32) has been emphasized importance of the cisternal anatomy during surgery. The subarachnoid space and related anatomic structures are protected by the anterior pontine membrane in case of tumors located epiduraly at the clival region, and facilitates creation of surgical dissection plane and protection of neural tissue.

The epidural space below the cranial bone, at the calvarial region, differs from its counterpart at the clivus. It is evident that the dura mater is a two-layered structure in the clivus, and the basilar plexus exists between these two layers (20, 23). As the epidural hematoma, involving the clival region, is located interdurally, not epidurally as in the calvarial region, it may be preferable to refer to these lesions as clival interdural hematomas. A hematoma on the right side of the petrous apex, in our second illustrative case, is therefore described as a biconvex hematoma within the text (Figure 4). The hematoma may be subdural or, because of the biconvex image, interdural; raising the cerebral layer of the clival dura mater in the region of the inferior petrosal sinus. A significant point requiring explanation is how such a fibrous tissue, having high adherence, could be separated from each other? The main clinical property of traumatic clival epidural, or interdural, is that hematomas are frequently associated with low GCS levels $(14,19)$. Severe injuries, such as, longitudinal clivus fracture, atlantoaxial dislocation, clival dural laceration and entrapment of the vertebrobasilar artery complex have been reported in these patients $(5,18,19,24)$. In trauma cases, it is possible to mechanically peel off the clival dura mater from below to above, by distraction of the dens towards the superior direction. Therefore, these types of the clival hemorrhage cases must be appraised for possible injury to the atlantoaxial structures (22).

Reports state, that the bleeding source usually causes disruption of the tectorial membrane, dura mater and fractured clival bone in the presented cases of the clival hematomas due to a trauma $(14,15,17)$. Casey et al. (3) have recently distinguished the clival hematomas as either epidural or subdural; and accomplished this classification by taking into account the tectorial membrane as the gauge. According to Casey's (3) classification, an epidural clival hematoma does not extend beyond the tectorial membrane, whereas a subdural clival hematoma may lead into the spinal subarachnoid space. However, the rigidity of the clival duramater prevents the slipping off, of the periosteal dura mater easily from the clival bone. Therefore, a classification depending on sagittal level of the clival hematoma may be questionable descripiton.

Another controversial issue regarding the clival hematoma term arises from the absorbtion of the hematoma, within a short period of time. We observed a disapperance of the hematoma on the third postraumatic day in case 1 (Figure 3). The patient had a clival subdural hemorrhage, according to our findings. There is no report explaining the mechanism of blood removal within days. However, it may be speculated that the tear of the arachnoid membrane or migration of subdural blood into the spinal region may cause rapid spontaneous resolution of a posttraumatic intracranial acute subdural hematoma $(1,13,27,30)$. Wong et al. (30) presented a similar case, that an acute cranial subdural hematoma redistrubuted into the spinal subdural space and disappeared after 45 hours intracranially.

Another question concerning the clival epidural or interdural hematoma is related to the existence of venous blood flow at the hematoma location. Since this area was filled with the venous blood of the basilar plexus dynamically, why does the blood not continue to fill the space? An epidural hematoma at the lateral calvarial region could be resolved spontaneously, because there is no venous sinus below $(6,28)$. It is possible that initial trauma causes bleeding at the outset, from the basilar plexus, but when the hematoma creates a sufficient level of pressure, cessation of bleeding may result. This type of spontaneous hemostasis is seen supratentorial area (10). In our case 2 (Figure 4), a right-sided clival biconvex hematoma looks like a clival epidural hematoma and was smaller than the subdural hematoma on the opposite side. We defined this as a biconvex hematoma, located at the right side of the patient because of we were unsure whether the hematoma was located in epidural or subdural space.

However, clival hematomas are not only caused by trauma, but may also occur spontaneously $(4,9,25,26)$. Brock at al. (2) presented a case of interdural hemorrhage due to infraclinoidal carotid artery aneurysm rupture. They explained the mechanism of interdural hemorrhage as the detachment of the cerebral layer of the dura mater, at the occulomotor trigone, due to high pressure bleeding from the aneurysm. The MRI of Brock's case (2) disclosed that the bleeding was extended to the medial side of the internal acoustic meatus; in addition, to the clival side, as well as to the posterior side of the foramen magnum. The blood having been clearly distributed to the SDS of the posterior fossa, encircling the arachnoid membrane covering the brainstem and cerebellum, of the patient. Development of an interdural hematoma between both dural layers, extending to the very firm fibrous trabeculations is not easily performed through an aneurysm rupture, according to our findings. Moreover, the expectation was that, the development carotico-cavernous fistula after bleeding, of their presented example (2). Brock's report (2) has very illustrative images for clarification of our description on the differentiation of SAS and SDS in the clival region. 


\section{CONCLUSION}

The anterior pontine membrane is the main structure which separates the subdural and subarachnoid spaces at the clival region. The hematomas of the clival region require to be evaluated with consideration given to the existence of the subdural and subarachnoid spaces. Additionally, the subarachnoid space and related anatomic structures are protected by the anterior pontine membrane in case of tumors located epidurally and subdurally at the clival region, and facilitates creation of surgical dissection plane and protection of neural tissue.

\section{REFERENCES}

1. Berker M, Gulsen S, Ozcan OE: Ultra rapid spontaneous resolution of acute posttraumatic subdural hematomas in patient with temporal linear fracture. Acta Neurochir (Wien) 145:715-757, 2003

2. Brock S, Prada F, Maccagnano E, Giombini S: Interdural hemorrhage of the posterior fossa due to infraclinoid carotid artery aneurysm rupture. Acta Neurochir 152: 1543-1546, 2010

3. Casey D, Chaudhary BR, Leach PA, Herwadkar A, Karabatsou K: Traumatic clival subdural hematoma in adult. J Neurosurg 110: 1238-1241, 2009

4. Cho CB, Park HK, Chough CK, Lee KJ: Spontaneous bilateral supratentorial subdural and retroclival extradural hematomas in association with cervical epidural venous engorgement. J Korean Neurosurg Soc 46: 172-175, 2009

5. Cho J, Moon CT, Kang HS, Choe WJ, Chang SK, Koh YC, Roh HG: Traumatic entrapment of the vertebrobasilar junction due to a longitudinal clival fracture: A case report. J Korean Med Sci 23: 747-751, 2008

6. Eom Kl, Park JT, Kim TY, Kim JM: Rapid spontaneous redistribution of acute epidural hematom: Case report and literature review. J Korean Neurosurg Soc 45: 96-98, 2009

7. Everton KL, Rassner UA, Osborn AG, Harnsberger HR: The occulomotor cistern: Anatomy and high resolution image. AJNR Am J Neuroradiol 29: 1344-1348, 2008

8. Frederickson RG: The subdural space as interpreted as a cellular layer of meninges. Anat Rec 230: 38-51, 1991

9. Goodman JM, Kuzma B, Britt P: Retroclival hematoma secondary to pituitary apoplexy. Surg Neurol 47: 79-80, 1997

10. Gulsen S, Sonmez E, Yilmaz C, Altinors N: Traumatic acute subdural hematoma extending from the posterior cranial fossa to the cerebellopontine angle. J Korean Neurosurg Soc 46 : 277-280, 2009

11. Haines DE, Harkey HL, Al-Mefty O:The 'Subdural' space: A new look at an outdated concept. Neurosurgery 32: 111-120, 1993

12. Kawase $T$, van Loveren $H$, Keller JT, Tew JM: Meningeal architecture of the cavernous sinus: Clinical and surgical implications. Neurosurgery 39: 527-536, 1996

13. Kundra SN, Kundra R: Extracranial redistribution causing rapid spontaneous resolution of acute subdural hematoma. Neurol India 53:124, 2005

14. Kurosu A, Amano K, Kubo O, Himuro H, Nagao T, Kobayashi $\mathrm{N}$, Kakinoki Y, Kitamura K: Clivus epidural hematoma - Case report. J Neurosurg 72: 660-662, 1990

15. Kwon TH, Joy H, Park YK, Chung HS: Traumatic retroclival hematoma: Case report. Neurol Med Chir 48: 347-350, 2008
16. Matsuno $H$, Rhoton AL, Peace D: Microsurgical anatomy of the posterior fossa cisterns. Neurosurgery 23:58-80, 1988

17. Mizushima $H$, Kobayashi N, Sawabe $Y$, Hanakawa K, Jinbo $\mathrm{H}$, Iıda $\mathrm{M}$, Iwata $\mathrm{T}$, Matsumoto K: Epidural hematoma of the clicus, case report. J Neurosurg 88: 590-593, 1998

18. Ochalski PG, Spiro RM, Fabio A, Kassam AB, Okonkwo DO: Fractures of the clivus: A contemporary series in the computed tomography era. Neurosurgery 65:1063-1069, 2009

19. Orrison WW, Rodge S, Kinard RE, Williams JE, Torvik A, Sackett JF, Amundsen P: Clivus epidural hematoma: A case report. Neurosurgery 18:194-196, 1986

20. Ozveren MF, Uchida K, Tekdemir I, Cobanoglu B, Akdemir I, Kawase T, Deda H: Dural and arachnoid membranous protection of the abducens nerve at the petroclival region. Skull Base Surg 12:181-188, 2002

21. Ozveren MF, Uchida K, Aiso S, Kawase T: Meningovenous structures of the petroclival region: Clinical importance for surgery and intravascular surgery. Neurosurgery 50: 829-837, 2002

22. Ratilal B, Castanho P, Vara Luiz C, Antunes JO: Traumatic clivus epidural hematoma: Case report and review of the literature. Surg Neurol 66: 200-202, 2006

23. Rhoton AL: The cavernous sinus, the cavernous venous plexus, and the carotid collar. Neurosurgery 51(4 Suppl): S375-410, 2002

24. Sato $S$, lida $H$, Hirayama $H$, Endo $M$, Ohwada T, Fujii K: Traumatic basilar artery occlusion caused by a fracture of the clivus. Neurol Med Chir (Tokyo) 41: 541-544, 2001

25. Schievink WI, Thompson RC, Loh CT, Maya MM: Spontaneous retroclival hematoma presenting as a thunderclap headache: case report. J Neurosurg 95: 522-524, 2001

26. Tomaras C, Horowitz BL, Harper RL: Spontaneous clivus hematoma: Case report and literature review. Neurosurgery 37: 123-124, 1996

27. Tsui EYK, Ma KF, Cheung YK, Chan JHM, Yuen MK: Rapid spontaneous resolution and redistribution of acute subdural hematoma in a patient with chronic alcoholism: A case report. Eur J Radiol 36:53-57, 2000

28. Tuncer R, Acıkbas C, Ucar T, Kazan S, Karasoy M, Savaren $M$ : Conservative management of extradural haematomas: effects of skull fractures on resorption rate. Acta Neurochir (Wien) 139: 203-207, 1997

29. Williams PL, Warwick R, Dyson M, Bannister LH: Gray's Anatomy. New York: Churcill Livingstone, 1989: 1086-1092

30. Wong ST, Yuen MK, Fok KF, Yuen SC, Yam KY, Fong D: Redistribution of hematoma to spinal subdural space as a mechanism for the rapid spontaneous resolution of posttraumatic intracranial acute subdural hematoma: Case report. Surgical Neurology 71: 99-102, 2009

31. Yasargil MG, Kasdaglis KK, Jain KK, Weber HP: Anatomical observations of the subarachnoid cisterns of the brain surgery. J Neurosurg 44: 298-302, 1976

32. Yasargil MG: The internal acoustic meatus and its meningeal layers: a microanatomical study. J Neurosurg 97: 1191-1197, 2002.

33. Zhang M, An PC: Liliequist's membrane is a fold of the arachnoid mater: study using sheep plastination and scanning electron microscopy. Neurosurgery 47: 902-909, 2000 